\title{
Hyalinobatrachium iaspidiense (Ayarzaguena, 1992) (Anura: Centrolenidae): first record in Amapá state, Brazil and geographic distribution map
}

\section{Yuri Breno Silva e Silva and Carlos Eduardo Costa-Campos*}

\author{
Universidade Federal do Amapá, Departamento de Ciências Biológicas e da Saúde, Laboratório de Herpetologia, Campus Marco Zero, \\ Rodovia Juscelino Kubitschek, km 02, Jardim Marco Zero, CEP 68.903-419, Macapá, AP, Brazil \\ * Corresponding author. E-mail: eduardocampos@unifap.br
}

\begin{abstract}
Wereport the first record of Hyalinobatrachium iaspidiense (Ayarzaguena, 1992) from Amapá state, Brazil. This record is $1,020 \mathrm{~km}$ east from the type locality at Quebrada de Jaspe, San Ignacio de Yuraní, Bolívar state, Venezuela, and extends the distribution of the species $345 \mathrm{~km}$ north of the nearest known locality in Para. We also provide a map of the localities reported in the literature.
\end{abstract}

Key words: Eastern Amazon, filling gap, geographic distribution, Amazon biome; glass frog

The family Centrolenidae Taylor, 1951, has long attracted the attention of biologists working in the Neotropics because of morphological and ecological characteristics of the species in the family, as well as its phylogenetic and biogeographic complexity (Castroviejo-Fisher et al. 2007; Cisneros-Heredia and McDiarmid 2007; Guayasamin et al. 2008). Centrolenids are distributed from southern Mexico through Central and South America to Bolivia, with an isolated group of species occurring in southeastern Brazil and northeastern Argentina (Frost 2015). At present, the roughly 150 recognized species of glass frogs are divided among 12 genera (Guayasamin et al. 2009; Castroviejo-Fisher et al. 2011).

During fieldwork in the municipality of Serra do Navio, Amapá state, one individual of Hyalinobatrachium iaspidiense was observed calling in lower forest strata (2.0-3.0 $\mathrm{m}$ above the ground or water) in vegetation overhanging a fast flowing segment of stream on 27 January 2013 in the Parque Natural Municipal do Cancão (00 $54^{\prime} 50^{\prime \prime} \mathrm{N}, 051^{\circ} 59^{\prime} 59.2^{\prime \prime} \mathrm{W}, 122 \mathrm{~m}$ above sea level). The individual was collected (permit SISBio 32651-2) and deposited in the Herpetological Collection of the Universidade Federal do Amapá (CECCAMPOS; voucher o0792).
Hyalinobatrachium iaspidiense may be distinguished from all other glass frogs by having, in life, a pale yellowish green dorsum with large, irregular green marks and small black spots (Figure 1). Ventrally, the parietal peritoneum and pericardium are completely transparent, revealing a red heart. The liver and digestive tract are covered by a white visceral peritoneum, while the peritoneal covering of the urinary bladder is transparent. Males of this species lack humeral spines (Guayasamin and North 2009; Castroviejo-Fisher et al. 2011).

Hyalinobatrachium iaspidiense is known from Brazil (Yáñez-Muñoz et al. 2009; Ávila-Pires et al. 2010; Castroviejo-Fisher et al. 2011), Ecuador (Yáñez-Muñoz et al. 2009; Guayasamin and North 2009), French Guiana (Lescure and Marty 2000; Castroviejo-Fisher et al. 2011), Guyana (Ernst et al. 2005; Cole et al. 2013), Peru

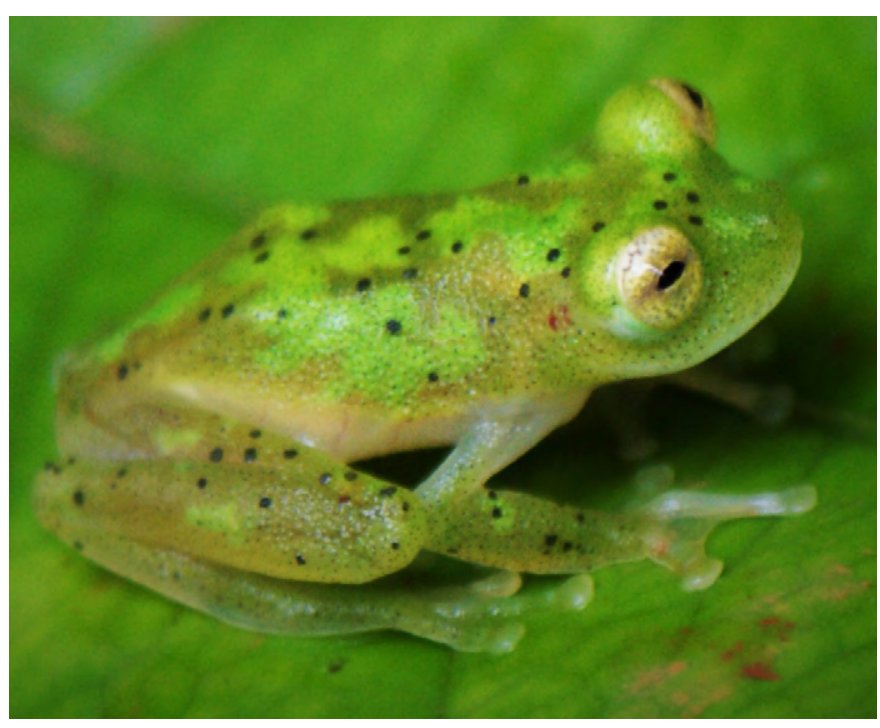

Figure 1. Adult male of Hyalinobatrachium iaspidiense (CECCAMPOS 00792, $\mathrm{SVL}=20.9 \mathrm{~mm}$ ) from the municipality of Serra do Navio, state of Amapá, Brazil. 


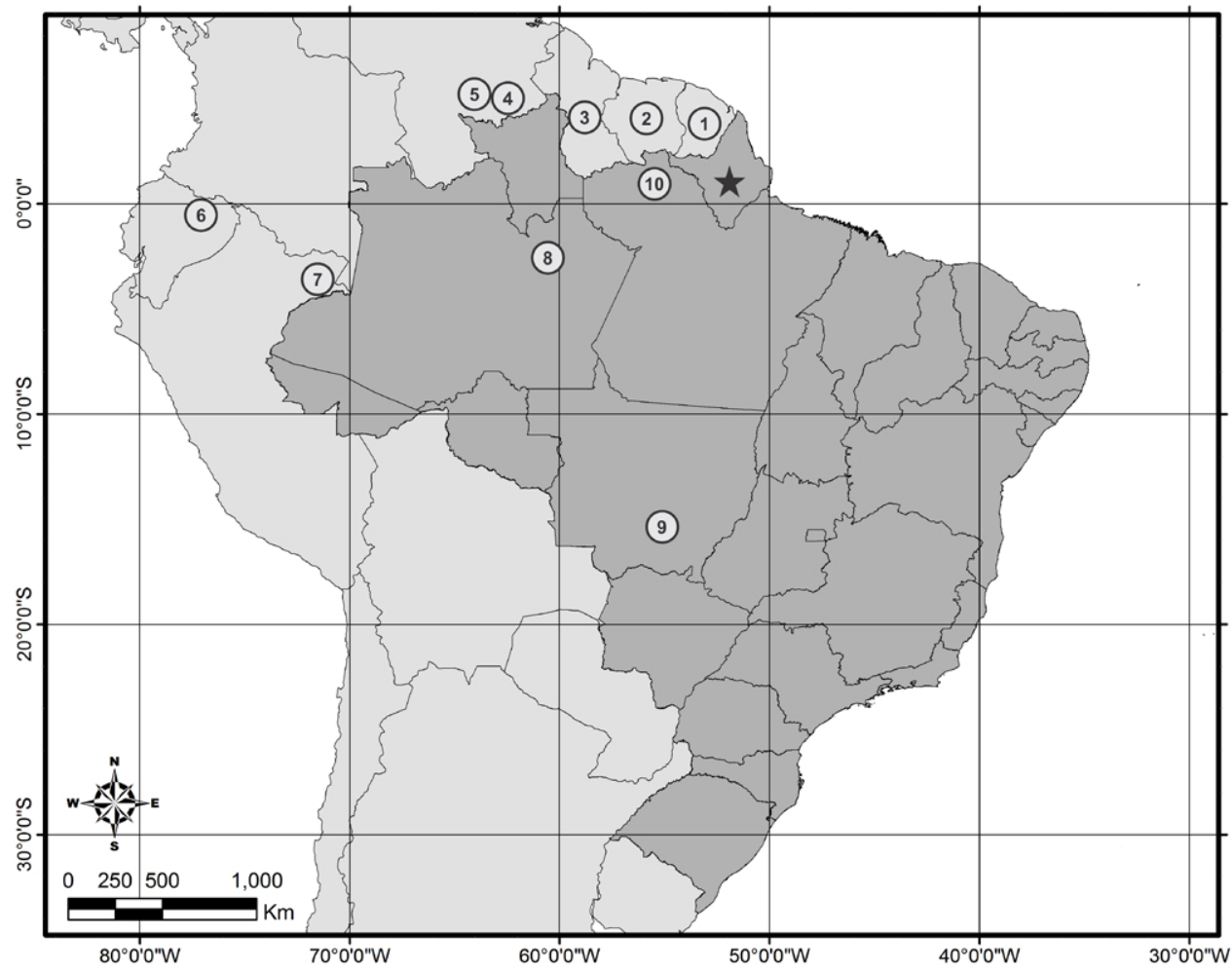

Figure 2. Map of northern South America showing the known localities of Hyalinobatrachium iaspidiense based on the new localities reported herein and literature records: (1) mountain areas of Kaw, Monts Trinité, Courcibo, and Saut Arataye/Nouragues Reserve, French Guiana; (2) Sipaliwini district, Suriname; (3) Mabura Hill Forest Reserve, central Guyana; (4) Caño Acoima, Delta Amacuro, Venezuela; (5) Quebrada de Jaspe, San Ignacio de Yuraní, Venezuela; (6) Cofán-Dureno territory, Ecuador; (7) Lago Preto-Paredón, Peru; (8) President Figueiredo, in the Guianan part of the state of Amazonas, Brazil; (9) lower River Cristalino region, in northern Mato Grosso, Brazil; (10) ESEC Grão-Pará Centre, state of Pará, Brazil. Star ( $\star$ ): new record of Hyalinobatrachium iaspidiense in the state of Amapá, Brazil.

(Yáñez-Muñoz et al. 2009; Castroviejo-Fisher et al. 2011), Suriname (Kok and Castroviejo-Fisher 2008; Ouboter and Jairam 2012), Venezuela (Señaris and Ayarzagüena 2005; Señaris and MacCulloch 2005; Castroviejo-Fisher et al. 2011), and is expected to occur in the Amazonian areas between the Ecuadorian and Peruvian localities and the Guiana region (Castroviejo-Fisher et al. 2011).

Here we report a new record of Hyalinobatrachium iaspidiense in the municipality of Serra do Navio $\left(00^{\circ} 54^{\prime} 50^{\prime \prime} \mathrm{N}, 051^{\circ} 59^{\prime} 59.2^{\prime \prime} \mathrm{W}\right)$, Amapá state, Brazil (Figure 2). This record is the first for Amapa and extends the known distribution of the species $1,020 \mathrm{~km}$ east from the type locality (Quebrada de Jaspe, San Ignacio de Yuraní, Bolívar state, Venezuela; $04^{\circ} 55^{\prime} \mathrm{N}$, $061^{\circ} \mathrm{O} 5^{\prime}$ $\mathrm{W}$; 800-1,000 $\mathrm{m}$ above sea level), $890 \mathrm{~km}$ east from Presidente Figueiredo in the Guianan part of the state of Amazonas, Brazil ( $\left.\mathrm{O}^{\circ} \mathrm{O}^{\prime} \mathrm{O} 4^{\prime \prime} \mathrm{S}, \mathrm{O}^{\circ} \mathrm{O}^{\circ} \mathrm{O}^{\prime} 3 \mathrm{O}^{\prime \prime} \mathrm{W}\right), 345 \mathrm{~km}$ north of Ecological Station Grão-Pará Centre, state of Pará, Brazil (00 $37^{\prime} 49.01^{\prime \prime}$ N, $055^{\circ} 43^{\prime} 42.60^{\prime \prime}$ W) and 1,230 $\mathrm{km}$ north from the lower Cristalino River in northern Mato Grosso state, Brazil ( $09^{\circ} 32^{\prime} 47^{\prime \prime}$ S, $055^{\circ} 47^{\prime} 38^{\prime \prime}$ W).

Accurate geographical distributions are crucial data for adequate conservation measures. The emergence of new distribution records shows that data on Brazilian amphibian distributions are deficient (Azevedo-Ramos and Galatti 2002; Silvano and Segalla 2005). This first record of Hyalinobatrachium iaspidiense in the state of Amapá confirms the importance of biological inventories in Amazonia.

\section{ACKNOWLEDGEMENTS}

We are grateful to Santiago Castroviejo-Fisher for confirming the identity of the specimen, and to A.P. Lima and W.E. Magnusson for valuable contributions to the manuscript and bibliography. ICMBio is acknowledged for the collecting permit. The Prefeitura Municipal de Serra do Navio gave permission to work in the Parque Natural Municipal do Cancão, and Marcela Marins (ICMBio) and the Pró-Reitoria de Extensão e Assuntos Comunitários (PROEAC/UNIFAP) provided logistical support.

\section{LITERATURE CITED}

Ávila-Pires, T.C.S., M.S. Hoogmoed and W.A. Rocha. 2010. Notes on the Vertebrates of northern Pará, Brazil: a forgotten part of the Guianan Region, I. Herpetofauna. Boletim do Museu Paraense Emílio Goeldi 5: 13-112.

Azevedo-Ramos, C. and U. Galatti. 2002. Patterns of amphibian diversity in Brazilian Amazonia: conservation implications. Biological Conservation 103: 103-111 doi: 10.1016/Sooo6-3207 (01)00129-X

Castroviejo-Fisher, S., I. De la Riva and C. Vila. 2007. Transparent frogs show potential of natural world. Nature 449: 972-972. doi: $10.1038 / 449972 b$ 
Castroviejo-Fisher, S., C. Vilà, J. Ayarzagüena, M. Blanc and R. Ernst. 2011. Species diversity of Hyalinobatrachium glassfrogs (Amphibia: Centrolenidae) from the Guiana Shield, with the description of two new species. Zootaxa 3132: 1-55.

Cisneros-Heredia, D.F. and R.W. McDiarmid. 2007. Revision of the characters of Centrolenidae (Amphibia: Anura: Athesphatanura), with comments on its taxonomy and the description of new taxa of glassfrogs. Zootaxa 1572: 1-82.

Cole, C.J., C.R. Townsend, R.P. Reynolds, R.D. MacCulloch and A. Lathrop. 2013. Amphibians and reptiles of Guyana, South America: illustrated keys, annotated species accounts, and a biogeographic synopsis. Proceedings of the Biological Society of Washington 125(4): 317-620. doi: 10.2988/0006-324X-125.4.317

Ernst, R.M.O. Rödel and D. Arjoon. 2005. On the cutting edge - The anuran fauna of the Mabura Hill Forest Reserve, Central Guyana. Salamandra 41: 179-194. http://www.salamandrajournal.com/index.php?option=com_docman \&task=doc_down load\&gid $=171 \&$ Itemid $=69$

Frost, D.R. 2015. Amphibian species of the world: an online reference. Version 6.o. American Museum of Natural History. Accessed at http://research.amnh.org/vz/herpetology/amphibia, 25 August 2015.

Guayasamin, J.M., S. Castroviejo-Fisher, J. Ayarzagüena, L. Trueb and C. Vilà. 2008. Phylogenetic relationships of glassfrogs (Centrolenidae) based on mitochondrial and nuclear genes. Molecular Phylogenetics and Evolution 48(2): 574-595. doi: 10.1016/j.ympev.2008.04.012

Guayasamin, J.M., S. Castroviejo-Fisher, L. Trueb, M. Rada and C. Vilà. 2009. Phylogenetic systematics of glassfrogs (Amphibia: Centrolenidae) and their sister taxon Allophryne ruthveni. Zootaxa 2100: 1-97.

Guayasamin, J.M. and S. North. 2009. Amphibia, Centrolenidae, Hyalinobatrachium iaspidiense: distribution extension. Check List
5(3): 526-529. http://www.checklist.org.br/getpdf?NGDoo4-09

Kok, P.J.R. and S. Castroviejo-Fisher. 2008. Glassfrogs (Anura: Centrolenidae) of Kaieteur National Park, Guyana, with notes on the distribution and taxonomy of some species of the family in the Guiana Shield. Zootaxa 1680: 25-53.

Lescure, J. and C. Marty. 2000. Atlas des amphibians de Guyane. Paris: Muséum National d'Histoire Naturelle. 388 pp.

Ouboter, P. E. and R. Jairam. 2012. Amphibians of Suriname. Boston: Brill Academic Publishers. 376 pp.

Señaris, J.C. and J. Ayarzagüena. 2005. Revisión taxonómica de la familia Centrolenidae (Amphibia, Anura) en Venezuela. Number 6. Sevilla: Publicaciones del Comité Español del Programa MaB y de la Red IberoMaB de la UNESCO. 337 pp.

Señaris, J.C. and R.D. MacCulloch. 2005. Amphibians; pp. 24-40, in: T. Hollowell and R.P. Reynolds (eds.). Checklist of the terrestrial vertebrates of the Guiana Shield. Bulletin of the Biological Society of Washington 13.

Silvano, D.L. and M.V. Segalla. 2005. Conservação de anfíbios no Brasil. Megadiversidade 1(1): 79-86.

Yáñez-Muñoz, M., P. Pérez-Peña and D. Cisneros-Heredia. 2009. New country records of Hyalinobatrachium iaspidiense (Amphibia, Anura, Centrolenidae) from the Amazonian lowlands of Ecuador and Peru. Herpetology Notes 2: 49-52. http://www.herpetology notes.seh-herpetology.org/Volume2_PDFs/Yanez-Munoz_et_ al_Herpetology_Notes_Volume2_pages_49-52.pdf

Author contributions: $C E C C$ and YBSS collected the data and CECC wrote the text.

Received: 4 August 2014

Accepted: 11 February 2016

Academic editor: Marcelo N. de C. Kokubum 